\title{
Promotion of Papua "Merbau" Iron Wood (Eusideroxylon Zwagerii) through in-Vitro Tissue Culture
}

\author{
Roy Marthen Rahanra ${ }^{1}$, Muhammad Imron², Dwi Yarmalinda ${ }^{3}$ \\ ${ }^{1,2,3}$ Department of Biology Education, Sekolah Tinggi Keguruan dan Ilmu Pendidikan (STKIP PGRI \\ Papua), Indonesia \\ rrahanra86@gmail.com,imroniim05@gmail.com,dwi.yarmalinda1@gmail.com
}

\begin{abstract}
Papua's ironwood comes from the merbau plant that inhabits the forests of Papua, one of which is in the Yapen Islands Regency, Serui City. In conventional cultivating ironwood for commercial purposes, there are various problems. When using powder and soil, a lot of sawdust is needed. In addition, the time required for planting seeds to produce shoots that are ready to be planted in the field takes a very long time of about 9-12 months. The first step in the cultivation of merbau tissue culture is to find the right formula for growth regulators. Auxins and cytokines are the right steps to stimulate merbau wood growth. It seems that the role of auxin (IAA) and cytokinin (BAP) in Murashige and Skoog media on Merbau Wood using cotyledon and meristem explants with good concentrations for shoot and plantlet formation was $1.0 \mathrm{mg} / \mathrm{l} I A A$ and $5,0 \mathrm{mg} /$ from the latest research using hormones including NAA, Chitin and BAP in Merbau (Eusideroxylon zwageri) wood culture. NAA concentration $1 \mathrm{mg} / \mathrm{l}$ (A4B5) formed shoots and callus, A4B1 (NAA $1 \mathrm{mg} / \mathrm{l}$; BAP $0 \mathrm{mg} / \mathrm{l}$ ) resulted in organogenesis and NAA concentration $0.2 \mathrm{mg} / \mathrm{l}$ without cytokinins (A2B1) produced multiple shoots. The interaction of the combination of auxin NAA $1 \mathrm{mg} / \mathrm{l}$ with BAP $0.6 \mathrm{mg} / \mathrm{l}$ (A4B7) gave the best response in embryosomatic formation in implanted explants. While the interaction of $N A A 0.2 \mathrm{mg} / \mathrm{l}$ with Kinetic $2 \mathrm{mg} / \mathrm{l}$ (A3B3) resulted in shoots and callus. The interaction of the combination of auxin NAA $1 \mathrm{mg} / \mathrm{l}$ with BAP $0.6 \mathrm{mg} / \mathrm{l}$ (A4B7) gave the best response in embryosomatic formation in implanted explants. While the interaction of NAA $0.2 \mathrm{mg} / \mathrm{l}$ with Kinetic $2 \mathrm{mg} / \mathrm{l}(A 3 B 3)$ resulted in shoots and callus. The interaction of the combination of auxin NAA $1 \mathrm{mg} / \mathrm{l}$ with BAP $0.6 \mathrm{mg} / \mathrm{l}$ (A4B7) gave the best response in embryosomatic formation in implanted explants. While the interaction of NAA 0.2 $m g /$ with Kinetic $2 \mathrm{mg} / \mathrm{l}(\mathrm{A} 3 \mathrm{~B} 3)$ resulted in shoots and callus.
\end{abstract}

Keywords: Merbau Papua Serui wood; eusideroxylon zwagerii; in-vitro tissue culture

\section{Introduction}

Merbau wood or usually better known as Kayu Besih, the name Merbau wood is the local name of the Papuan people. Iron wood or Merbau wood is in Papua as the main raw material for making building instructions. Merbau wood species is a type of merbau plant that inhabits the forests of Papua, both in coastal areas and in forests. Currently, the existence of merbau plants in the forests in Papua is very small as a result of overexploitation and illegal logging so that they are close to extinction. Arifin (2006) there are efforts to preserve and rejuvenate using conventional methods such as through seeds, but the length of the germination phase (9-12 months) is a limiting factor. Propagation using vegetative methods by cuttings does not seem to be successful. Tissue cultivation is an alternative to overcome the shortage/scarcity of merbau seeds in bulk and cheaply. The initial step taken in the cultivation of ironwood tissue was to find the right growth regulator (ZPT) formula, the type of explant, and then acclimatize the plantlets produced by Ariwahono, (2010).

The advantages of this method are that it can be done in bulk (a lot) with one seedling, requires little planting material, is faster so it will be cheap/economical, easy to handle the seeds produced, the risk of damage in transport to the field is small. Medium that is widely used in tissue culture, namely Medium MS (Murashige and Skong) is widely used in 
propagation through tissue culture. Hadiyono and Zulkarnain (1991). One of the success of morphogenesis of tissue cultivation is determined by explants. Parts of plants that can be used as explants can be in the form of adult or young embryos, the parts of the sprouts that are the most responsive, because they are still juvenile, such as cotyledons, hypocotyls; and shoots of sprouts (Rineksane, 2000). Root formation will be induced more easily in medium with a concentration level of $0.01-0.3 \mathrm{mg} / \mathrm{l} \mathrm{NAA}$, further explained by Gunawan (1991), for growth of shoot cultivation it is necessary to add $0.5 \mathrm{mg} / \mathrm{l} 0$, hypocotyl; and shoots of sprouts (Rineksane, 2000). The results showed that most shoots were produced from media supplemented with 30-40 M BAP and 0.5 NAA. According to Cahyono (1995), tissue culture in foreign materials is referred to as tissue culture.

Culture is cultivation and tissue is a group of cells that have the same shape and function. So, tissue culture means cultivating a plant tissue into small plants that have properties like the parent. Tissue culture is one way of vegetative propagation of plants. Multiply and reproduce into a complete plant. The main principle of tissue culture technique is plant propagation using vegetative parts of plants using Murashige and Skoog (MS) media in a sterile environment. Generally, wood is very difficult to propagate with conventional seeds. Ironwood whose habitat is in coastal areas is characterized by an elongated body shape but many branches produced, its body condition is very strong in maintaining growth stability even though the salinity level of salt content is very high, but the resistance and development of ironwood is normal in the body. The life of ironwood that grows in the forest is characterized by its elongated body, not many branches, its size is very large, its leaf shape is compound and its seeds are very black. In general, ironwood has layers of chips so that when isolated it sometimes experiences obstacles Bhojwani, 1983.

Research using special tissue culture applications on ironwood plants using biotechnology methods is still low in Indonesia. Cytokinins are derivatives of adenine, this group plays an important role in regulating cell division and morphogenesis. The interaction and balance between auxin and cytokinin given in the medium and produced endogenously by plants, determines the direction of development of a culture that is grown (George, 1999). Auxins and cytokines are growth regulators that are usually needed in tissue culture media and are given in concentrations appropriate to the desired growth (George, 1984). Murashige (1974) root production at once. Root formation will be induced more easily in medium with NAA levels or 0.01-0.03 mg/l, further explained by Gunawan (1987), For the growth of oncidium shoot culture, it is necessary to add $0.5 \mathrm{mg} / \mathrm{L}$ NAA. It seems that the role of auxin (IAA) and cytokinin (BAP) in Murashige and Skoog media in avocado using cedar endosperm explants with good concentrations for plantlet formation was $1.0 \mathrm{mg} / \mathrm{l} \mathrm{IAA}$ and $5.0 \mathrm{mg} / \mathrm{l} \mathrm{BAP}$.

(Chawla, HS 2000) Based on the problems above, the authors are interested in solving research research with the problems attached above through research with the title "Effectiveness of the Development of Merbau Seeds Propagation (Eusideroxylon zwageri) Through Intra-Meristem and Cotyledon Culture Vitro. It seems that the role of auxin (IAA) and cytokinin (BAP) in Murashige and Skoog media in avocado using cedar endosperm explants with good concentrations for plantlet formation was $1.0 \mathrm{mg} / \mathrm{l} \mathrm{IAA}$ and $5.0 \mathrm{mg} / \mathrm{l} \mathrm{BAP}$.

\section{Research Purposes}

This study aims to determine the interaction between growth regulators (auxin NAA and Kinetin) the next hormone treatment (NAA and BAP) by stimulating the growth of cothledons and meristems in producing shoot propagation of ironwood (E. zwageri). 


\section{Research Methods}

\subsection{Variable Operational Definition}

Independent variables : Combination of concentration of growth regulators NAA with kinetin and NAA with BAP.

Dependent variable : Formation of callus and shoots.

\subsection{Research Procedure}

\section{a. Tools and Materials}

In the implementation of this research, basically all the instruments used in the research are aseptic and must be used regardless of the laboratory rules, the instruments used include:

\section{b. Tools (Research Instruments)}

Autoclave, culture bottles, petri dishes, Erlenmeyer, beaker, scissors, measuring cup, hot plate, analytical balance, magnetic stirrer, oven, scalpel knife, knife, $\mathrm{pH}$ meter, pipette, sprayer, laminar air flow. Gerungan, RFI 1997

\section{c. Ingredient}

1) Explan

Sources of explants were ironwood meristems and cotyledons obtained from ironwood ores. Sources of seeds can be from farmers in the Yapen Islands district, Ansus Sand Village.

\section{d. Data Analysis}

Observational data on the percentage of reaction of explants were analyzed by ANOVA, if they were significantly different, Duncan's multiple region test was conducted (Gaspersz, 1993).

\section{Discussion}

\section{Interaction of NAA and Kinetin on Ironwood Explants (E. zwageri) Using Cotyledon}

\section{Culture}

The interaction of NAA and chitin showed various percentages of shoot and/or callus formation cultured on MS medium using NAA auxin with cytokinin Kinetin after 1 month of research, namely in November 2020 with the results of ANOVA analysis as follows:

Table 1. The Interaction November 2020 with the results of ANOVA analysis

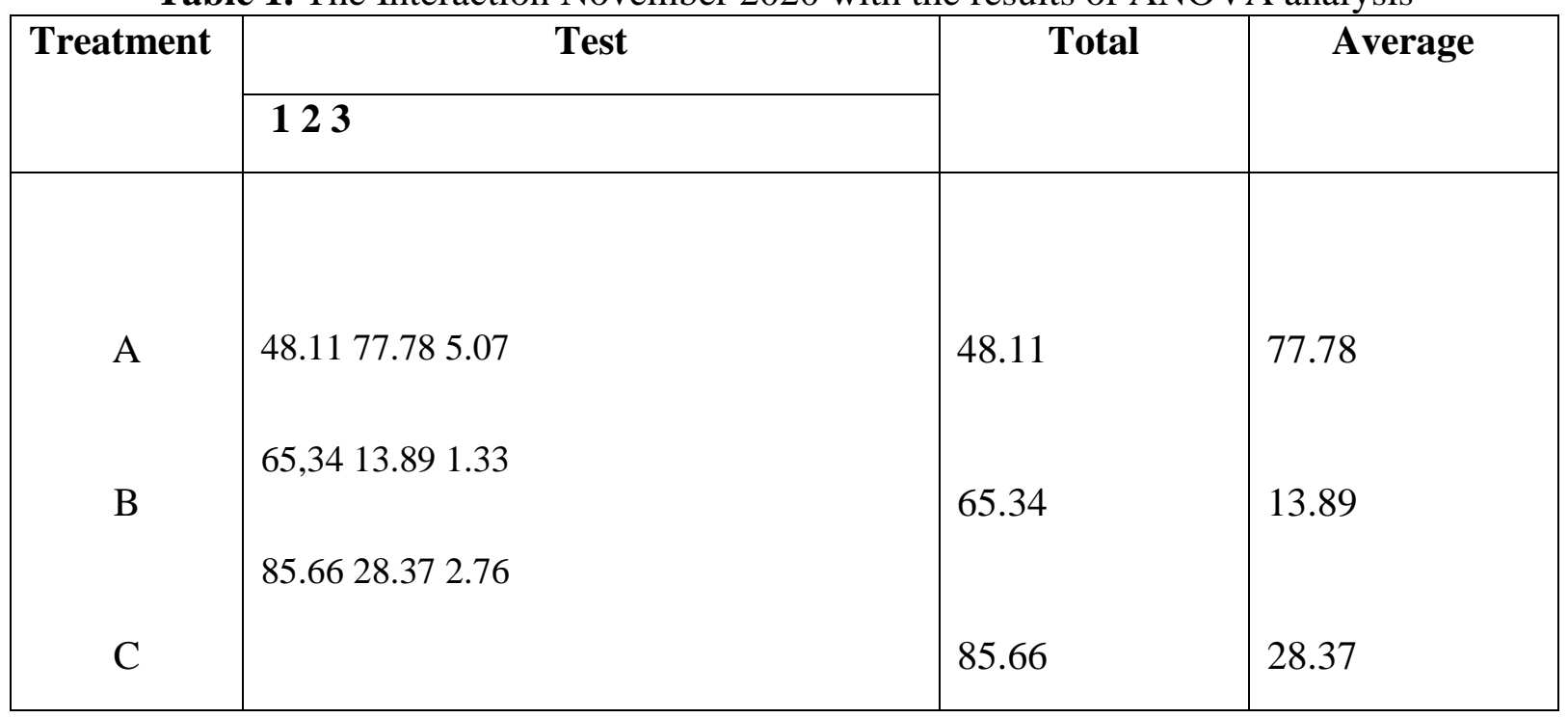




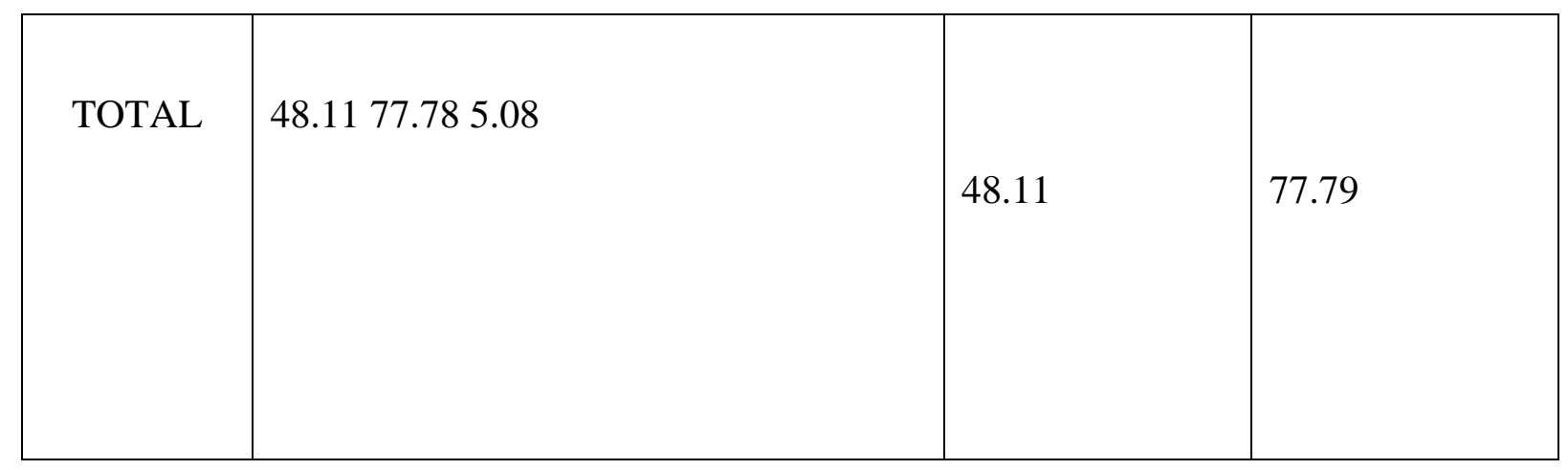

$*$ Real at $=0.05 ; \mathrm{tn}=$ not real at $=0.05$

Duncan's multiple test was used to further test the reaction of E. zwageri van Houtte explants because the null hypothesis was rejected. Based on the analysis of variance, very real results were obtained at the 5\% level, so to test which treatment was the best among the treatments tried, it was continued by using Duncan's multiple area test. Conclusion : The concentration of NAA and Chitin was able to give a real effect to form plantlets in the process of development and growth of explants, while the NAA and BAP treatment in meristem culture could also give a good effect to form callus. The unreal influence $=0.01$ showed changes in growth development that were not the same in spurring the daily growth of the Papua Besi wood plant, except between other treatment constructions according to the best growing media.Abidin, 1985. Mrbau wood explants (E. zwageri) which showed growth in the form of callus and buds were found at concentrations A3B1, A1B1, A1B2, A4B2, A1B3, A2B3, A3B3, A1B4 A3B1, A1B1, A1B2, A4B2, A1B3, A2B3, A3B3, A1B A2B4. Is a growth regulator derived from the NAA and Chitin group. The next process of callus was subcultured callus cells for this subculture reason, in order to obtain the multiplication of explant cells on merbau wood (E. zwageri) in large quantities but indirectly the state of cell development was hampered so that the cells formed shoots and roots.

Default Error Calculation:

$$
\begin{aligned}
& S \bar{Y}=\left(\frac{S^{2}}{r}\right)^{1 / 2} \\
& =\left(\frac{\mathrm{KTG}}{r}\right)^{1 / 2} \\
& =\left(\frac{1875}{3}\right)^{1 / 2} \\
& =77
\end{aligned}
$$

The shortest real area using the formula $\mathrm{Rp}=\mathrm{rp}$ to the table is significant at the level of $5 \%$. 


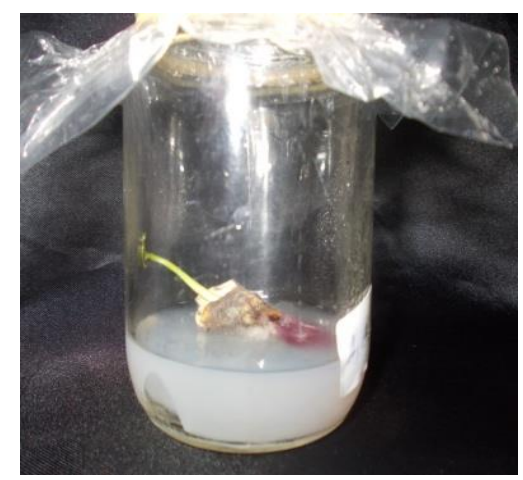

(Figure a). A3B3" focus 0,5

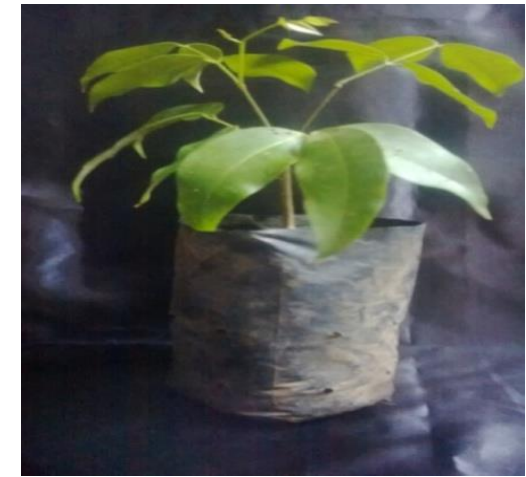

(Figure a). A3B3" focus 0,5

Figure 1. Response of Explants in Woody Cotyledons (E. zwageri)

Description: Figure a) Multiplication Results

Figure b) Acclimatization Results

\section{Conclusion}

The results of this study can draw the conclusion that the growth regulator auxin NAA greatly affects and responds to the propagation and growth of Papuan ironwood (E. zwageri). At the concentration of NAA $1 \mathrm{mg} / \mathrm{L}$ (A4B5) shoots and callus were formed, A4B1 (NAA 1 $\mathrm{mg} / \mathrm{L}$; BAP $0 \mathrm{mg} / \mathrm{l}$ ) occurred organogenesis and concentration

NAA $0.5 \mathrm{mg} / \mathrm{L}$ without cytokinin (A2B1) produced double shoots. The combination of auxin NAA $1 \mathrm{mg} / \mathrm{L}$ with BAP $0.6 \mathrm{mg} / \mathrm{l}$ (A4B7) gave the best response in embryosomatic and cornell formation (E. zwageri). Meanwhile, the interaction of $0.1 \mathrm{mg} / \mathrm{l} \mathrm{NAA}$ with $2 \mathrm{mg} / \mathrm{l}$ kinetic (A3B3) resulted in shoots and callus.

\section{References}

Abidin, 1985. Umumnya komposisi utama media tanam Kultur jaringan, terdiri dari hormon (zat pengatur tumbuh) pegembangan budidaya tanaman

Arifin, Z. dan Pasambuna, E. 2006. Kemampuan kayu besi Menurut Jenis Bibit. Jurusan kehutanan

Ariwahono, (2010) Keadan Populasi Kayu besi di Indonesia. PT. Bumi Aksara

Bhojwani, S. S. and M. K. Razdan. 1983. Plant Tissue Culture: Theory and Practice. Elsevier Sci. Publ. Co: Amsterdam.

Cahyono, B. 1995. Kayu besi Usaha Tani. Kanisius, Yogyakarta.

Chawla, H.S. 2000. Introduction to Plant Biotechnology. Science Publisher, Inc. USA.

Hadiyono dan Zulkarnain. 1991. Perbanyakan Tanaman Lada (Piper nigrum L) melalui Teknik Kultur

Gaspersz, V. 1993. Metode Rancangan Percobaan. Armico: Bandung. Jaringan. Jambi laporan penelitian Fakultas Pertanian Jambi

George, E. F. and P. D. Sherrington. 1984. Plant Propagation by Tissue Culture. Exegetics Ltd. Eversley. Basingstoke: England. 709 p.

Gorogo serta Kumar et al (1999). Pegembangan tanaman Budidaya Kultur Jaringan serta pemanfaatan Hormon.

Gunawan, L. W. 1987. Teknik Kultur Jaringan. Laboratorium Kultur Jaringan Tanaman. PAU Bioteknologi IPB. Bogor.

Gerungan, R.F.I. 1997. Budidaya In vitro Tanaman Gladious sp. Laporan

Rineksane, I. A. 2000. Perbanyakan Tanaman Manggis Secara In-Vitro dengan Perlakuan Kadar BAP, Air Kelapa, dan Arang Aktif. Tesis PPS-UGM. Yogyakarta. 69 hal. 